\title{
Kejadian Kekerasan Pada Perempuan Selama Masa Pandemi Covid-19
}

\author{
Winda Ayu Fazraningtyas,, Dini Rahmayani1, Indana Fitriani Rahmah2 \\ 1Departemen Keperawatan Maternitas, Program Studi Sarjana Keperawatan dan Profesi Ners, \\ Fakultas Kesehatan, Universitas Sari Mulia \\ 2Mahasiswa Profesi Ners, Program Profesi Ners, Fakultas Kesehatan, Universitas Sari Mulia \\ *correspondence author: HP: +6281357430301 \\ E-mail:ns.winda26@gmail.com | windaayu@unism.ac.id
}

DOI: $10.33859 /$ dksm.v11i1.550

\begin{abstract}
Abstrak
LATAR BELAKANG Kekerasan terhadap perempuan, terutama kekerasan pada pasangan dan kekerasan seksual adalah masalah kesehatan masyarakat yang utama dan merupakan pelanggaran terhadap hak asasi perempuan. Data yang diterbitkan oleh WHO (2018) menunjukkan bahwa sekitar 1 dari $3(35 \%)$ perempuan di seluruh dunia telah mengalami kekerasan. Hal ini semakin bertambah selama masa pandemi COVID-19 yang terjadi hampir di seluruh belahan dunia. Pembatasan sosial yang dilakukan selama masa pandemi ini berdampak pada perekonomian, membuat ekonomi keluarga terpuruk, dan berimbas pada situasi dan kondisi perempuan. Segala kegiatan yang terpusat di rumah membuat beban domestik yang sangat besar bagi perempuan, mulai dari mengurus rumah hingga memastikan anak-anak mengakses pendidikan dari rumah.
\end{abstract}

TUJUAN Penelitian ini bertujuan untuk menganalisis kejadian kekerasan pada perempuan yang terjadi selama masa pandemi COVID-19 .

METODE Metode yang digunakan dalam penulisan ini menggunakan pendekatan narrative review. Artikel yang digunakan pada studi ini diambil dari Google Scholar dan Pubmed dengan total artikel yang sesuai dengan kriteria adalah 10 artikel. Semua artikel yang digunakan dalam studi ini berasal dari tahun 2020.

HASIL Terdapat peningkatan kejadian kekerasan pada perempuan. Dampak kekerasan perempuan dapat mempengaruhi di gangguan reproduksi seperti ketidakteraturan menstruasi, dan gangguan dalam proses kehamilan, dan gangguan mental seperti munculnya kecemasan, takut, letih, dan stress, bahkan tidak jarang berdampak pada gangguan makan dan tidur

KESIMPULAN Kekerasan yang terjadi pada perempuan ini semakin meningkat seiring dengan semakin lamanya pandemi COVID-19 ini berlangsung. Hal ini dikarenakan pembatasan sosial yang diterapkan untuk mengurangi penyebaran dari pandemi ini menyebabkan perempuan dan pasangan harus menetap dalam satu rumah dan tidak dapat menghindarinya. Untuk itu, manajemen emosional sangat diperlukan untuk meminimalisir kejadian kekerasan pada perempuan ini.

Kata Kunci: pandemi COVID-19, Kekerasan pada Perempuan 


\begin{abstract}
Background: Violence against women, especially violence against partners and sexual violence is a major public health problem and one of a violation of women's human rights. According to WHO (2018) emphasized that around 1 in 3 (35\%) women worldwide have experienced violence. Furthermore, this increased during the COVID-19 pandemic which occurred in almost all parts of the world. The social restrictions imposed during the pandemic have an impact on the economy, making the family economy worse, and impacting the situation and condition of women. All activities centered at home create a huge domestic burden for women, from managing the house to making sure children access education from home.
\end{abstract}

Aim: This study aimed to analyze the incidence of violence against women that occurred during the COVID-19 pandemic.

Method: This study used a narrative review approach. The articles used in this study were taken from Google Scholar and also Pubmed with a total of 10 articles that fit the criteria. All articles used in this study date from 2020.

Result: There is an increase in the incidence of violence against women during the COVID-19 pandemic. The impact of violence on women can affect reproductive disorders such as menstrual irregularities, and disorders in the process of pregnancy, and mental disorders such as the emergence of anxiety, fear, fatigue, and stress, even not infrequently have an impact on eating and sleep disorders.

Conclusion: The violence that occurred in these women increased along with the length of the COVID-19 pandemic. This is because the social restrictions that are implemented to reduce the spread of this pandemic cause women and couples to settle in one house and cannot avoid it. Therefore, emotional management is needed to minimize the incidence of violence against women during the COVID-19 pandemic.

Kata Kunci: the COVID-19 pandemic, violence against women

\section{Pendahuluan}

Kesetaraan gender merupakan salah satu target yang telah ditentukan dalam tujuan pengembangan dunia yang dikenal dengan Suistanable Development Goals (SDG's) yaitu tujuan ke 5 dari 17 tujuan dimana targetnya yang akan dicapai sampai tahun 2030 adalah mengurangi terjadinya kekerasan pada perempuan serta kesertaan gender (United Nation, n.d.; WHO, 2018). Data yang diterbitkan oleh WHO (2018) menunjukkan bahwa sekitar 1 dari 3 (35\%) perempuan di seluruh dunia telah mengalami kekerasan pasangan intim baik fisik maupun seksual atau kekerasan non-seksual lainnya. 
Dinamika Kesehatan Jurnal Kebidanan dan Keperawatan Vol 11 No. 1 Juli 2020 ( ISSN: 2086-3454 EISSN: 2549-4058) url: http://ojs.dinamikakesehatan.unism.ac.id DOI : https://doi.org/10.33859/dksm.v11il

Kejadian Kekerasan Pada Perempuan Selama Masa Pandemi Covid-19

Data yang dijabarkan dalam

Worldometer menjelaskan bahwa usia > 60 tahun memiliki kemungkinan kematian yang lebih tinggi. Demikian pula halnya di kasus COVID-19 yang terjadi di Italia, sebanyak $73,1 \%$ kasus terjadi pada usia > 50 tahun. Namun, sebanyak 25,6\% COVID-19 di Italia terjadi pada usia produktif menurut data dari Statista. Di Indonesia sendiri, hingga tanggal 13 April 2020 terdapat sebanyak 4.557 kasus dengan 399 kematian yang telah tersebar hampir di seluruh wilayah Indonesia.

COVID-19 ini sangat mudah menyebar melalui droplet. Semua orang secara umum rentan terinfeksi. Pneumonia Coronavirus jenis baru dapat terjadi pada pasien immunocompromis dan populasi normal, bergantung paparan jumlah virus. Jika kita terpapar virus dalam jumlah besar dalam satu waktu, dapat menimbulkan penyakit walaupun sistem imun tubuh berfungsi normal. Orangorang dengan sistem imun lemah seperti orang tua, perempuan hamil, dan kondisi lainnya, penyakit dapat secara progresif lebih cepat dan lebih parah (Huang et al., 2020; Wang et al.,
2020; Fehr et al, 2015). Oleh karena itu, WHO

(2020) segera menerapkan status darurat kesehatan masyarakat yang sering dikenal dengan pandemi.

Pandemi COVID-19 sudah menyebar hampir di seluruh belahan dunia, dengan adanya permasalahan ini menyebabkan permasalahan lain yang menyertai pandemi ini. Laporan tentang peningkatan kekerasan perempuan di saat pandemi ini sudah didapatkan dari Australia, Brasil, Cina dan Amerika Serikat. Ditambah lagi, di Kabupaten Jianli China (Provinsi Hubei Tengah), kantor polisi sudah menerima 162 laporan kekerasan pasangan suami dan istri yang mengalami peningkatan 3 kali lipat dari Bulan Februari (Wanqing, 2020).

Di Indonesia sendiri, data terkait dengan KDRT yang terjadi selama masa pandemi ini masih sangat terbatas. Demikian pula, pada sumber referensi yang mambahas terkait permasalahan ini. Untuk itu, mengetahui akar permasalahan yang terjadi menjadi sangat penting untuk membantu menyelamatkan perempuan. Adapun narrative review ini 
Dinamika Kesehatan Jurnal Kebidanan dan Keperawatan Vol 11 No. 1 Juli 2020 ( ISSN: 2086-3454 EISSN: 2549-4058) url: http://ojs.dinamikakesehatan.unism.ac.id DOI : https://doi.org/10.33859/dksm.v11il

Kejadian Kekerasan Pada Perempuan Selama Masa Pandemi Covid-19

bertujuan untuk menganalisis kejadian

kekerasan pada perempuan selama pandemi

COVID-19 berdasarkan studi empiris lima tahun terakhir.

\section{Metode}

Studi ini menggunakan pendekatan narative review yang mana artikel didapatkan dari pencarian pada Google Scholar dan Pubmed. Artikel yang digunakan adalah jurnal international dengan full text, serta memiliki kesesuaian isi dan tujuan dari studi ini. Adapun kata kunci yang digunakan dalam pencarian adalah "Women Violence and COVID 19" dan "Violence against Women and COVID-19". Total artikel yang digunakan dalam studi ini adalah 10 artikel.

\section{Hasil}

Hasil pada literature review ini sebanyak 10 literatur jurnal menggunakan jurnal-jurnal dari berbagai negara dan membahas tentang kejadian perilaku kekerasan pada peremuan di saat pandemi COVID-19. Adapun tahun terbit jurnal ini semuanya di tahun 2020 dan jurnal yang didapatkan semuanya adalah jurnal internasional. Jurnal yang didapatkan terbit di beberapa sumber jurnal seperti International
Journal of Mental Health Nursing, MedEd

Publish, Archives Of Psychiatriy Research, Journal Of Clinical Nursing, American Academy of Pediatric, Eclinical Medicine, The BMJ, dan International Journal Of Equity in Health. Berdasarkan artikel yang ditemukan, didapatkan bahwa 4 jurnal membahas kejadian kekerasan rumah tangga khususnya perempuan dengan kisaran $10-30 \%$ dan mengalami peningkatan 2 kali lipat untuk terjadinya kekerasan. Selain itu, terdapat 2 jurnal yang membahas tentang dampak terjadinya kekerasan perempuan, dan terdapat 4 jurnal yang membahas cara mengurangi terjadinya kekerasan pada perempuan.

Berdasarkan artikel yang didapatkan diketahui bahwa lebih dari $30 \%$ perempuan terancam kekerasan seksual. WHO menyebutkan KDRT di Ethiopia menembus angka di atas $71 \%$. Sementara korban KDRT di Cina 90\% adalah kaum perempuan. Menurut laporan China Women Federation (CWF), dari tiga perempuan di negara ini, salah satunya menjadi korban kekerasan berumah tangga. 
Dinamika Kesehatan Jurnal Kebidanan dan Keperawatan Vol 11 No. 1 Juli 2020 ( ISSN: 2086-3454 EISSN: 2549-4058) url: http://ojs.dinamikakesehatan.unism.ac.id DOI : https://doi.org/10.33859/dksm.v11il

Kejadian Kekerasan Pada Perempuan Selama Masa Pandemi Covid-19

Bentuk kekerasan pada perempuan yang

paling banyak dilakukan adalah kekerasan

fisik ringan berupa mendorong istri,

selanjutnya adalah kekerasan ekonomi ringan

berupa tidak memenuhi kebutuhan rumah

tangga dan kekerasan seksual ringan berupa

menghina dengan kata-kata yang mengandung

unsur seksual (Bradbury-Jones et al., 2020;

Usher et al., 2020).

Beberapa faktor penyebab terjadi

KDRT, yaitu faktor individu (seperti korban

penelantaran anak, penyimpangan psikologis,

dan riwayat kekerasan di masa lalu), faktor

keluarga (seperti pola pengasuhan yang buruk,

konflik dalam pernikahan, kekerasan oleh

pasangan, rendahnya status sosial ekonomi,

keterlibatan orang lain dalam masalah

kekerasan), faktor komunitas (seperti

kemiskinan, angka kriminalitas tinggi,

mobilitas penduduk tinggi, banyaknya

pengangguran, perdagangan obat terlarang

lemahnya kebijakan institusi, kurang nya

sarana pelayanan korban, faktor situasional),

dan faktor Lingkungan Sosial (seperti

perubahan lingkungan sosial yang cepat, kesenjangan ekonomi, kesenjangan gender, kemiskinan, lemahnya jejaring ekonomi, lemahnya penegakan hukum, budaya yang mendukung kekerasan, tingginya penggunaan senjata api ilegal, masa konflik/pascakonflik (Dyer et al., 2020; van Gelder et al., 2020; Yndo et al., 2020).

\section{Pembahasan}

Berdasarkan Lembaga Bantuan Hukum Jakarta dari Asosiasi Perempuan Indonesia untuk Keadilan (LBH APIK) dalam The Jakarta Post (2020) menunjukkan bahwa tercatat 59 kasus kekerasan dalam rumah tangga, pemerkosaan, kekerasan seksual dan pornografi online dari tanggal 16 hingga 30 Maret 2020, hanya dalam waktu \pm 2 minggu sudah tercatat lebih dari 50 kasus. Hal tersebut belum termasuk kasus yang tidak tercatat dan kasus-kasus dari luar wilayah Jakarta, karena tidak semua perempuan mau dan mampu membuka permasalahan yang terjadi dalam rumah tangga. Di samping itu, fokus penanganan COVID-19 yang ada masih berkutat dengan bagaimana pencegahan dan penanganan yang tepat secara umum, masih 
Dinamika Kesehatan Jurnal Kebidanan dan Keperawatan Vol 11 No. 1 Juli 2020 ( ISSN: 2086-3454 EISSN: 2549-4058) url: http://ojs.dinamikakesehatan.unism.ac.id DOI : https://doi.org/10.33859/dksm.v11i1

Kejadian Kekerasan Pada Perempuan Selama Masa Pandemi Covid-19

kurang melihat dampak yang terjadi bagi

individu, khususnya kaum perempuan.

Menurut United Nation (n.d.), perempuan akan menjadi orang yang paling terpukul oleh pandemi ini, tetapi mereka juga akan menjadi tulang punggung pemulihan dalam komunitas. Padahal bila mengingat kembali tujuan dari Sustainable Development Goals (SGDs) pada Tahun 2030, pada tujuan ke-5 menyebutkan bahwa "mencapai kesetaraan gender dan memberdayakan semua perempuan dan anak perempuan" dengan indikator meniadakan semua bentuk kekerasan terhadap semua perempuan dan anak perempuan di ruang publik dan pribadi, termasuk perdagangan manusia dan eksploitasi seksual lainnya. Bahkan, berdasarkan The New York Times (2020) menjelaskan bahwa data KDRT yang meningkat menunjukkan bahwa kekerasan dalam rumah tangga bertindak seperti infeksi oportunistik, berkembang dalam kondisi yang diciptakan oleh pandemi dalam upaya pembatasan sosial untuk pencegahan penularannya pandemi ini.
Pembatasan sosial berdampak pada perekonomian, membuat ekonomi keluarga terpuruk, dan berimbas pada situasi dan kondisi perempuan. Segala kegiatan yang terpusat di rumah membuat beban domestik yang sangat besar bagi perempuan, mulai dari mengurus rumah hingga memastikan anakanak mengakses pendidikan dari rumah. Dalam situasi tersebut, perempuan rentan tertular virus corona baru karena perempuan lebih sering keluar rumah dibandingkan anggota keluarga lainnya dalam upaya untuk memenuhi kebutuhan makanan keluarga (Bradbury-Jones et al., 2020; Crawley et al., 2020; Mlambo-Ngcuka, 2020; Roesch et al., 2020; Usher et al., 2020). Di sisi lain, struktur sosial masyarakat yang masih patriarki juga mengharuskan perempuan berperan sebagai pengasuh, pendidik, memastikan kesehatan keluarga, menyiapkan makanan (Rahmayani, 2017). Beban perempuan akan bertambah apabila bekerja di luar rumah dan kadang harus bekerja dari rumah. Di tengah situasi pandemi COVID-19 dan keterpurukan ekonomi, ketika perempuan dianggap tidak mampu 
Dinamika Kesehatan Jurnal Kebidanan dan Keperawatan Vol 11 No. 1 Juli 2020 ( ISSN: 2086-3454 EISSN: 2549-4058) url: http://ojs.dinamikakesehatan.unism.ac.id DOI : https://doi.org/10.33859/dksm.v11il

Kejadian Kekerasan Pada Perempuan Selama Masa Pandemi Covid-19

menjalankan fungsi domestiknya, perempuan

rentan mengalami KDRT (Dyer et al., 2020;

Paterman et al., 2020; Yndo et al., 2020).

KDRT akan dapat terjadi berulang kali, dan bahkan terjadi secara terus menerus seperti halnya lingkaran setan yang tidak akan pernah putus. Disamping itu, hal ini juga berdampak lebih berat bagi korban kekerasan tersebut karena kekerasan memang mempunyai siklus, seperti tergambar dibawah ini :

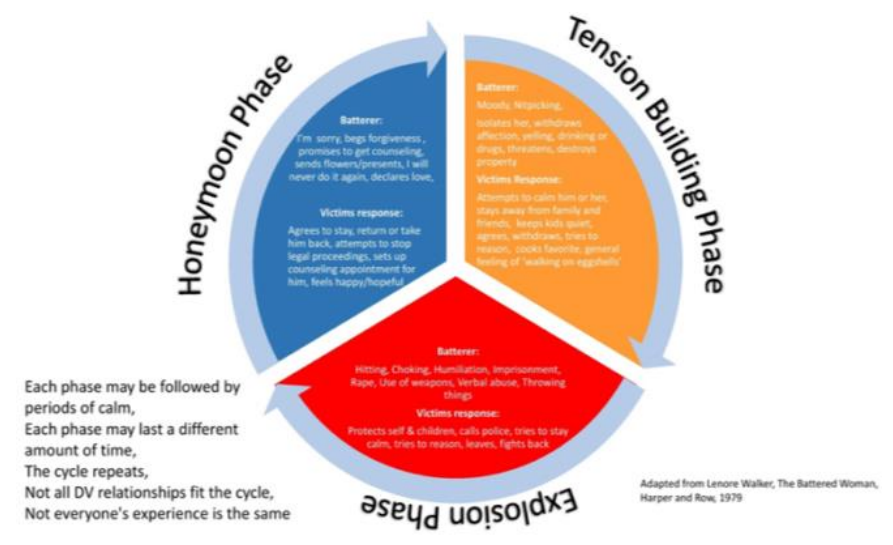

Gambar 1. Siklus KDRT

Pada saat mencermati siklus terjadinya

kekerasan tersebut, ada kebingungan yang terjadi, mengapa pelaku melakukan kekerasan lagi setelah meminta maaf atau menyesali. Bukan hanya itu, pelaku juga bisa berperilaku yang jauh lebih baik kepada korban, tetapi kembali mengulanginya. Pada saat pelaku mulai melakukan kekerasan terhadap perempuan, maka untuk melakukannya kembali seolah-olah menjadi lebih mudah dan akhirnya menjadi sebuah kebiasaan. Kekerasan yang dilakukan berulang, bisa saja lebih dari kekerasan yang pernah dilakukan pada sebelumnya dan berdampak yang lebih berat dari sebelumnya. Apabila siklus ini terus berlangsung dan tidak dapat dihentikan atau diputus mata rantainya, maka angka kejadian KDRT akan terus bertambah dan dapat mempengaruhi kualitas hidup seseorang, baik itu korban maupun pelakunya (Harnoko, 2010; Rahmayani, 2017; Yndo et al., 2019). Hal ini akhirnya akan berdampak pada generasi penerus bangsa, dalam hal ini, adalah anak sebagai saksi terjadinya KDRT dan anak tersebut dapat menjadi korban kekerasan yang sedikit banyaknya mempengaruhi perkembangan mental anak, serta memiliki contoh untuk melakukan KDRT dikemudian hari (Dapic et al., 2020).

Dengan tingginya kejadian KDRT dapat memberi dampak buruk bagi kesehatan perempuan selaku korban. Dampak tersebut meliputi rasa takut, cemas, letih, stress post 
Dinamika Kesehatan Jurnal Kebidanan dan Keperawatan Vol 11 No. 1 Juli 2020 ( ISSN: 2086-3454 EISSN: 2549-4058) url: http://ojs.dinamikakesehatan.unism.ac.id DOI : https://doi.org/10.33859/dksm.v11il

Kejadian Kekerasan Pada Perempuan Selama Masa Pandemi Covid-19

traumatic, serta gangguan makan dan tidur

yang merupakan reaksi panjang dari tindak

kekerasan. Namun, tidak jarang akibat tindak

kekerasan terhadap istri juga mengakibatkan

kesehatan reproduksi terganggu secara

biologis. Pada perempuan yang mengalami

kekerasan dalam rumah tangga dapat

menyebabkan terganggunya kesehatan

reproduksi, diantaranya gangguan menstruasi,

bahkan wanita tersebut dapat mengalami

menopause lebih awal (Humpreys, et al., 2020;

van Gelder et al., 2020; Paoole et al., 2020).

\section{Ucapan terima kasih}

Penelitian ini didukung penuh oleh

Universitas Sari Mulia di Banjarmasin.

\section{Daftar Pustaka}

Bradbury-Jones, C., \& Isham, L. (2020). The pandemic paradox: The consequences of COVID-19 on domestic violence. Journal of clinical nursing, 29(13-14), 2047-2049.

https://doi.org/10.1111/jocn.15296.

Crawley, E., Loades, M., Feder, G., Logan, S., Redwood, S., \& Macleod, J. (2020). Wider collateral damage to children in the UK because of the social distancing measures designed to reduce the impact of COVID-19 in adults. BMJ paediatrics open, $\quad 4(1), \quad$ e000701. https://doi.org/10.1136/bmjpo-2020000701.
Fehr, A. R., \& Perlman, S. (2015). Coronaviruses: an overview of their replication and pathogenesis. Methods in molecular biology (Clifton, N.J.), 1282, 1-23. https://doi.org/10.1007/978-14939-2438-7_1.

Dapic, M.R., Flander, G.B., \& Prijatelj, K. (2020). Children behind closed doors due to COVID-19 isolation: Abuse, neglect and domestoc violence. Archieve of Psychiatry Research, 56, 181-192. doi: 10.20471/dec.2020.56.02.06.

Dyer, H., Stelly, D., \& Watson G.L. (2020). Intimate partner violence: Using standardized patients to improve traumainformed care in the era of the COVID19 pandemic. MedEdPublish, 9, [1], 79. https://doi.org/10.15694/mep.2020.0000 79.1.

Harnoko, B. Rudi. 2010. Dibalik tindak kekerasan terhadap perempuan. Vol. No 1, juli 2010. Muwazah. Didownload dari http://e-journal.stain pekalongan.ac.id/, tanggal 24 Maret 2020.

Huang, C., Wang, Y., Li, X., Ren, L., Zhao, J., $\mathrm{Hu}$, Y., Zhang, L., Fan, G., Xu, J., Gu, X., Cheng, Z., Yu, T., Xia, J., Wei, Y., Wu, W., Xie, X., Yin, W., Li, H., Liu, M., Xiao, Y., ... Cao, B. (2020). Clinical features of patients infected with 2019 novel coronavirus in Wuhan, China. Lancet (London, England), 395(10223), 497-506.

https://doi.org/10.1016/S01406736(20)30183-5.

Humphreys, K. L., Myint, M. T., \& Zeanah, C. H. (2020). Increased Risk for Family Violence During the COVID-19 Pandemic. Pediatrics, e20200982. Advance online publication. https://doi.org/10.1542/peds.2020-0982.

Mlambo-Ngcuka, P. (2020). UN Women: Violence against women and girls: the shadow pandemic. 
https://www.unwomen.org/en/news/storie s/2020/4/statement-ed-phumzileviolence-against-women-duringpandemic.

Oktavianti, T.I. (2020). The Jakarta Post: Jakarta records spike in domestic violence reports during work-fromhome period. https://www.thejakartapost.com/news/2 020/04/07/jakarta-records-spike-indomestic-violence-reports-during-workfrom-home-period.html.

Paterman, A., Potts, A., O’Donnell, M., Thompson, K., Shah, N., Oertelt-Prigione, S., \& van Gelder, N. (2020). Pandemics and violence against women and children. Center for Global Development. https://resourcecentre.savethechildren.net Lnode/17250/pdf/pandemics-andvawg.pdf.

Poole, D. N., Escudero, D. J., Gostin, L. O., Leblang, D., \& Talbot, E. A. (2020). Responding to the COVID-19 pandemic in complex humanitarian crises. International journal for equity in health, 19(1),41.https://doi.org/10.1186/s12939 -020-01162-y.

Rahmayani, D. (2017). Kesehatan reproduksi: Kekerasan terhadap perempuan. Jakarta: In Media.

Roesch, E., Amin, A., Gupta, J., \& GarcíaMoreno, C. (2020). Violence against women during covid-19 pandemic restrictions. BMJ (Clinical research ed.), 369,m1712.https://doi.org/10.1136/bmj. $\mathrm{m} 1712$.

Taub, A. (2020). The New York Times: A New Covid-19 Crisis: Domestic Abuse Rises Worldwide.

https://www.nytimes.com/2020/04/06/wo $\mathrm{rld} /$ coronavirus-domestic-violence.html.

United Nations. (n.d.). Sustainable Development Goal 5. https://sustainabledevelopment.un.org/sd g5.

Usher, K., Bhullar, N., Durkin, J., Gyamfi, N., \& Jackson, D. (2020). Family violence and COVID-19: Increased vulnerability and reduced options for support. International journal of mental health nursing, 10.1111/inm.12735. Advance online publication. https://doi.org/10.1111/inm.12735.

van Gelder, N., Peterman, A., Potts, A., O'Donnell, M., Thompson, K., Shah, N., Oertelt-Prigione, S., \& Gender and COVID-19 working group (2020). COVID-19: Reducing the risk of infection might increase the risk of intimate partner violence. EClinicalMedicine, 21, 100348. Advance online publication. https://doi.org/10.1016/j.eclinm.2020.10 $\underline{0348}$

Wang, Z., Qiang, W., \& Ke, H. (2020). A Handbook of 2019-nCoV Pneumonia Control and Prevention. China: Hubei Science and Technologi Press.

Wanqing, Z. (2020). Domestic Violence Cases Surge During COVID-19 Epidemic. https://www.sixthtone.com/news/10052 53/domestic-violence-cases-surgeduring-covid-19-epidemic.

World Health Organization. (2020). Novel Coronavirus (2019-nCoV). Situation Report-1Januari 21.

World Health Organization. (2020). COVID19 and violence against women: What the health sector/system can do. https://www.who.int/reproductivehealth/p ublications/vaw-covid-19/en/.

Yndo, M. C., Weston, R., \& Marshall, L. L. (2019). Social Reactions to Intimate Partner Violence Disclosure Among LowIncome, Ethnically Diverse Community 
Dinamika Kesehatan Jurnal Kebidanan dan Keperawatan Vol 11 No. 1 Juli 2020 ( ISSN: 2086-3454 EISSN: 2549-4058) url: http://ojs.dinamikakesehatan.unism.ac.id DOI : https://doi.org/10.33859/dksm.v11i1

Kejadian Kekerasan Pada Perempuan Selama Masa Pandemi Covid-19

Women. Violence against women, 25(7),

817-838.

https://doi.org/10.1177/10778012188055

79. 